\title{
Autoliths: Reinterpreting mafic microgranular enclaves in granites and their implications
}

\author{
CARMEN RODRÍGUEZ ${ }^{1}$ ANTONIO CASTRO ${ }^{2}$ \\ ${ }^{1}$ Institute of Earth Sciences Jaume Almera CSIC, Lluis Sole \\ Sabaris s/n, 08028 Barcelona, Spain \\ crodriguez@ictja@csic.es \\ ${ }^{2}$ Instituto de Geociencias IGEO, CSIC- Universidad \\ Complutense de Madrid (CSIC - UCM), Calle Doctor \\ Severo Ochoa 7, 4 ${ }^{\text {a }}$ Planta, Ciudad Universitaria, 28040 \\ Madrid, España \\ antonio.castro@csic.es
}

Mafic microgranular enclaves are common in all kind of granites, being a characteristic feature of I-type granodiorites and tonalites of Andean-type and post-collisional batholiths. The interpretation of enclaves as autoliths - fragments from the chilled margins of magma conduits dragged by magma during ascent - opens a new window to reconstruct the physical state of magmas at the early stages of emplacement. In particular, autoliths reveal two essential features of magmas that are obscured by slow crystallization in plutons. These are the crystallinity (crystal fraction) and the nearliquidus relations. More than $90 \%$ of the magma was liquid at the time of quenching at the side walls of conduits. Phenocrysts (about $10 \mathrm{vol} \%$ ) are represented by plagioclase and Px, the latter transformed into amphibole (clots) by late slow cooling. The presence of primary amphibole, biotite and $\mathrm{Fe}$-oxides in the quenched groundmass indicate that most maficity (Fe+Mg-Ti) corresponds to primary liquid composition, and not acquired by restite entrainment. The implications of autoliths are explored using examples from varied classical localities and compared with near-liquidus phase relation models. The results lead to re-interpret textures and geochemical features that have received a different interpretation along decades, and support a near-liquidus temperature for granitic magma genesis. 